\title{
RESEARCH
}

Open Access

\section{The Grand Tour: Keynes and Goodwin go to Greece}

\author{
Eduardo Amaral Haddad ${ }^{1,3^{*}}$ (D), Natalia Cotarelli ${ }^{1}$, Thiago Cavalcante Simonato ${ }^{2}$, Vinicius Almeida Vale ${ }^{4}$ \\ and Jaqueline Coelho Visentin ${ }^{1}$
}

*Correspondence: ehaddad@usp.br

${ }^{3}$ Department of Economics, FEAUSP, Av. Prof. Luciano Gualberto, 908, FEA I, Cidade Universitária, São Paulo, SP 05508-900, Brazil

Full list of author information is available at the end of the article

\begin{abstract}
The impact of the crisis in the Greek economy was not uniform among the regions, threatening socioeconomic cohesion. In this paper, we explore the concept of the income multiplier in a multi-regional input-output setting, in the context of the Greek recession, showing empirical evidence for the increasing magnitude of the multiplier during the recession period. The main results reveal a complex system of interregional relations on some of whose structural characteristics the cyclical reaction paths of the regions depends. In this case, the use of fiscal instruments to stimulate local activity in the regions may bring about important implications for regional inequality in Greece.

Keywords: Interregional input-output analysis, Keynesian multiplier, Recessions, Greece, Austerity policy, Countercyclical regional policy

JEL Classifications: E12, E62, R11
\end{abstract}

\section{Introduction}

Robert Solow (2015) has recently commented on Richard Goodwin's article 'The Multiplier as a Matrix' (Goodwin 1949) recalling the analogy between the Leontief-like matrix multiplier and the Kahn-Keynes multiplier. ${ }^{1}$ By including households as one of the sectors, Goodwin's multi-sectorial approach has paved the way to replicate Kahn-Keynes by calculating an aggregate national income multiplier as a weighted average of all sector multipliers.

Having Wassily Leontief as its most influential source of inspiration, the quest for relaxing the aggregative nature of the Keynesian system has nudged not only Goodwin's initial scientific accomplishments, but also other early authors', especially Chipman (1950), who developed, at the same time as Goodwin, the notion of sector multipliers. The idea that a net increase in the rate of home investment (and other autonomous injections) propagates in the entire system generating higher-order effects is even more appealing in a multi-sectorial context. Rather than attempting to create a complete model of the economy, the main interest was to trace some of the effects of such injections in the system (Solow 2015).

${ }^{1}$ Kahn (1931) and Keynes (1936). the source, provide a link to the Creative Commons licence, and indicate if changes were made. The images or other third party material in this article are included in the article's Creative Commons licence, unless indicated otherwise in a credit line to the material. If material is not included in the article's Creative Commons licence and your intended use is not permitted by statutory regulation or exceeds the permitted use, you will need to obtain permission directly from the copyright holder. To view a copy of this licence, visit http://creativeco mmons.org/licenses/by/4.0/ 
While, for the sake of simplicity, Goodwin has focused on a closed economy in his 1949 article, using direct references to Keynes, Chipman acknowledged in his more general setting the strong influence from the work by Fritz Machlup on the foreign trade multiplier. Machlup (1943) had presented a framework that considered ripple effects in the context of international trade. He has initially developed the idea of the foreign trade multiplier in a demand-driven two-country framework, in which an increase in autonomous income in country A generates, through import leakages, an increase in the income of country B, i.e. part of the increase in the income of A would be spent on imports from country B. Part of this income transfer from A to B, in a second round, would return to A via A's exports to B. This process would continue until the income transfers became negligible. Building on that, Metzler (1950) attempted to generalize this idea by considering a model of an economic system composed of $n$ regions or countries. Goodwin (1980) revisited this debate presenting a simple, largely static, prototypical analysis using statistically derived data to illustrate how the foreign trade matrix multiplier could be decomposed to separate the internal effects of a demand expansion (or contraction) from the international feedback operating through the trade network.

Walter Isard further developed Machlup-Chipmann's foreign trade multiplier in the context of regions within a single country. As this notion worked for countries linked by trade flows, this could be applied for domestic trading regions as well. In a simplified formulation, the interregional trade multiplier would indicate the multiple regional income as the sum of regional investments and exports. Thus, changes in regional income would result from (and as a multiple of) a change in regional investment, exports, or both. The key point is that, in complex economic structures, neither sectors nor regions are isolated entities. By employing a multi-sectorial interregional framework, one may learn something about the cyclical sensitivities of other regions and how their cycles may be spread to her region. This type of study leads to a more precise formulation of multiplier effects and of the mechanisms by which cycles are spatially transmitted within the system of regions. It centres around the interregional trade multiplier, a concept closely akin to Keynesian doctrine (Isard 1960). Further on, Miyazawa (1976) developed an important work on embedding household consumption in input-output models. Hewings et al. (1999) provide a comprehensive overview of the explicit demographic economic interactions in the Miyazawa structure and its applications.

In all those instances, the theory embedded in the concept of multipliers is short-run in nature in the same sense as Keynes' General Theory is a short-run theory: it is a static theory of income and not a theory of growth, which makes it less applicable to longer periods of analysis (Metzler 1950). The magnitude of this well-known macroeconomic mechanism has been an object of controversy regarding its application in the realm of economic policies. Charles (2016) reports on several recent studies that have shown that the fiscal multiplier is endogenous to the level of economic activity, increasing during recessions and decreasing during the boom. In fact, Auerbach and Gorodnichenko (2012) show that, in a recession, the multiplier may be larger, especially at short horizons. Despite contested by mainstream economists, the logical policy implication recommends the expansion of public expenditures during a recession period to sustain effective demand and the level of profits to increase employment. 
The aforementioned theoretical developments, associated with seminal works by Keynes and Goodwin, provided the bases for a strand of empirical research dedicated to understand economic systems, structures and processes, and their change through time and space. A body of literature has emerged relying on historical input-output databases as valuable sources of information for uncovering some of the important dimensions of structural change in an economy, and for unravelling the various sources of growth of national and regional economies (e.g. Feldman et al. 1987; Dewhurst 1993; Sonis et al. 1996; Dietzenbacher and Los 2000; Hitomi et al. 2000; Romero et al. 2009; Zhang and Lahr 2014). The common focus relies very often on the role played by technical change and changes in final demand, the latter reflecting changes in social preferences (Haddad 2014). Other approaches based on input-output systems have attempted to analyse the structure of multi-regional trade flows. Feedback loop analysis has been used for both interregional (Sonis et al. 1995, 2001) and intercountry input-output tables (Sonis et al. 1993) providing an opportunity to examine the hierarchy of intra- and inter-regional trade flows within an integrated economic system.

Such framework is particularly interesting for assessing the spatial propagation of the Greek crisis. From 2010 to 2013, the period of our analysis, the real GDP fell almost 23\% in Greece, with a decrease in government expenditures by $25 \%$ and in investments by roughly $45 \%$, with a small increase in international exports by less than $2 \%$. In the same period, real GRP from the 13 NUTS-2 regions varied from $-14.7 \%$, in Western Macedonia to $-31.9 \%$ in Eastern Macedonia and Thrace. In the case of Greece, geography has played an important role since the spatial pattern of the initial impacts of the austerity measures was influenced by the geographical presence of the public sector. However, when taking into account indirect and induced effects, the regional structure of the Greek economy has also influenced the spatial propagation of the impacts through a complex diffusion of the multiplier effects. Though small, the Greek economy is not internally homogenous, presenting variations across both industries and regions. Thus, the anti-crisis, austerity, measures taken in Greece, though horizontal in their nature, may have significantly differentiated implications across space (Psycharis et al. 2014).

In what follows, we present some basic information on the uneven regional impacts of the Greek crisis to motivate further our case study. We will use a unique database comprising two fully specified interregional input-output tables for Greece, estimated for the years 2010 and $2013 .{ }^{2}$ Despite some difficulties associated with the process of estimation of the database that generates some caveats in the forthcoming analysis, discussed in the coming sessions, we provide some insights to be further explored in future studies.

What has happened to the national income multiplier during this period? Have Greek regions adjusted in different ways with implications for the changing value of their respective multipliers, and, consequently, for the design of countercyclical regional policy prescriptions? Using techniques of structural decomposition analysis (SDA) for comparing different economic structures in the context of partitioned input-output systems, we will be able to assess the main driving forces of the changes faced by the 
Greek regions in the first years of the economic recession and fiscal austerity. We show that changes in final demand-mainly in investment and government demand-were the main drivers of the setback of the economy. However, technical change was also an important element to drive changes in regional income. In spite of its smaller magnitude, it has played different roles for different regions. While in some regions technical coefficients have adjusted through stronger internal linkages that favoured the internalization of the multiplier effects, other regions increased their dependence upon the rest of the system, increasing the existing leakages. Overall, the national income multiplier for Greece increased by 5.9\% from 2010 to 2013. Moreover, all regions also faced increases in their value-added (income) multipliers during the recession period, notwithstanding differences in the intensity and in the spatial distribution of the changes.

Thus, the objectives of this paper are twofold. On one hand, we bring additional evidence for the internal propagation of the Greek crisis from a regional perspective. On the other hand, we look at the interdependence of technology, domestic and international trade linkages, and components of aggregate demand as possible sources of the variation in the spread of the effects initiated with the austerity programme. While the results are to be qualified, we hope they will serve to shed light on the mechanisms of changes in regional income in the context of the Greek crisis and to stimulate further work in this line of research.

\section{Regional dimensions of the Greek crisis}

The effects of the economic crisis in Greece have been the object of different studies. One of the important elements of the Greek crisis refers to the alleged fact that the Greek authorities had falsified debt information. Both the deficit and the accumulated stock of debt were far higher than the official numbers. The Greek debt crisis started in 2009, triggered by the financial crisis, and exacerbated by the weakness of the Greek economy and by the lack of confidence in the country's statistics. In early 2010, the European Commission condemned Greece for falsifying data about its public finance. At the time, the new data showed a fiscal deficit almost four times bigger than the previous announced, which prompted swift downgrades of Greek debt. To stabilize the fiscal account and regain the confidence of the financial markets, the Greek government implemented a series of drastic austerity measures. However, in the face of uncertainty surrounding the impact of these measures, Greek securities were downgraded to junk bonds status and the prices of Greek bonds tumbled with the risk of insolvency of the country.

Most of the studies that have analysed the Greek crisis have as their focus the impact of the austerity measures on the country's economy often justified to be undertaken by the use of modern DSGE models. The ex post modelling-based argument that measures of fiscal austerity in Greece have failed, raised by Betz and Carayannis (2015), suggests that the Polak Model (Polak 1957), that was also used to justify the policy of austerity in assisting an economically troubled nation, did not immediately solve the fiscal problem but only deepened the Greek fiscal crisis, increasing unemployment, recession, and government instability. In his diagnostics on the contemporary austerity policies, of which the Greek case was part, Boyer (2012) identifies as one of the fallacies in the debate the 
neglect of crowding in and competitive mechanisms that could quickly stop the downwards adjustments and trigger a vigorous recovery of the economies under stress. ${ }^{3}$

Along with Betz and Carayannis (2015), Krugman (2013) defended that the Greek crisis was a "godsend" for anti-Keynesians that had been warning how dangerous fiscal profligacy can be. At that time, many economists suggested that a certain level of debt hurts growth, ${ }^{4}$ and a theory known as "expansionary austerity", which defends that cuts in the government spending increase the output, became remarkably influential. However, data for the Greek economy have shown that these propositions were wrong. As stated by Paul Krugman, the data proved that the austerity programme has had major adverse economic effects. More than that, the downturns in the economy were more or less proportional to the degree of austerity.

The deterioration in the Greek situation after the adoption of fiscal austerity measures was such that, in 2015, prominent economists, including Thomas Piketty, Jeffrey Sachs, and Dani Rodrik, wrote an open letter to ask Chancellor Angela Merkel to rethink the punitive and failed programme on the recent years that "crushed the Greek economy, led to mass unemployment and a collapse of banking system". According to these economists, the humanitarian impact was colossal. In fact, fiscal consolidation through spending cuts and tax increases has been shown to have raised the risk of increased poverty and inequality (Matsaganis and Leventi 2013).

Moreover, the impact of the crisis in the Greek economy was not uniform among the regions, threatening socioeconomic cohesion (see Table 1 and Fig. 1). Its 'geographical footprint' has been examined, for instance, in Psycharis et al. (2014) who have shown that metropolitan areas and regions that are based on manufacturing activities seem to have been more vulnerable to the crisis while places that are based on tourism, such as islands, were usually more resistant. This result is confirmed in Artelaris (2017) that presented further evidence that less advanced and/or urbanized regions are more resilient during the period of crisis. The sectorial composition is also used as an element to explain regional differences in unemployment effects (Karafolas and Alexandrakis 2015).

The spatial concentration of economic activities and the degree of regional specialization or diversification seem to affect regional reactions to economic shocks (Richardson 1969; Attaran 1986; Berry 1988; Martin 2012; Eraydin 2016; Martin et al. 2016). Empirical evidence for Greece suggests that tourism has been among the most resilient sectors of the Greek economy and therefore regions that are specialized in tourism-based activities (e.g. South Aegean) are also more resilient to the crisis. On the contrary, regions specialized in sectors such as banks and real estate, financial intermediaries and insurance companies (e.g. Attica) that are more exposed to international fluctuations and more affected by the economic crisis tended to be more affected during the recession (Psycharis et al. 2014). In the case of tourism, nonetheless, Papatheodorou and Arvanitis (2014) claim that any generalization should be treated with caution due to the complex character of the particular activity and the inherent asymmetries between domestic and international tourism. They suggest that, in the context of the crisis, a new geography of

${ }^{3}$ Different macroeconomic projections that criticized the official projections of DSGE models have been produced by the Keynesian stock-flow consistent model of Greece of the Levy Economics Institute (Papadimitriou et al. 2013a, b).

${ }^{4}$ Reinhart and Rogoff (2010), for instance, argued that not just debt hurts growth, but that there is a threshold when debt is higher than $90 \%$ of GDP, economic growth stalls. 
Table 1 Basic socioeconomic indicators for Greece, 2010-2013. Source: Hellenic Statistical Authority

\begin{tabular}{|c|c|c|c|c|c|c|c|c|c|}
\hline \multirow[t]{2}{*}{ Regions } & \multicolumn{3}{|l|}{ Population } & \multicolumn{3}{|c|}{ GRP/GDP (in 2013 million $€$ ) } & \multicolumn{3}{|c|}{$\begin{array}{l}\text { Per Capita GRP/GDP (in } 2013 \\
\text { €) }\end{array}$} \\
\hline & 2013 & $\%$ & $\begin{array}{l}\text { Growth } \\
2010- \\
2013\end{array}$ & 2013 & $\%$ & $\begin{array}{l}\text { Growth } \\
2010- \\
2013\end{array}$ & 2013 & $\begin{array}{l}\text { Share } \\
\text { of national }\end{array}$ & $\begin{array}{l}\text { Growth } \\
2010- \\
2013\end{array}$ \\
\hline Attica & $39,12,849$ & 35.56 & -2.25 & $77,736.77$ & 48.51 & -23.33 & 19,867 & 1.36 & -21.56 \\
\hline $\begin{array}{l}\text { North } \\
\text { Aegean }\end{array}$ & $1,99,478$ & 1.81 & -0.35 & 2282.15 & 1.42 & -21.92 & 11,441 & 0.79 & -21.65 \\
\hline $\begin{array}{l}\text { South } \\
\text { Aegean }\end{array}$ & $3,34,652$ & 3.04 & 0.60 & 5306.91 & 3.31 & -20.10 & 15,858 & 1.09 & -20.57 \\
\hline Crete & $6,30,085$ & 5.73 & 1.12 & 7596.56 & 4.74 & -23.79 & 12,056 & 0.83 & -24.63 \\
\hline $\begin{array}{l}\text { Eastern } \\
\text { Mac- } \\
\text { edonia } \\
\text { and } \\
\text { Thrace }\end{array}$ & $6,10,102$ & 5.54 & 0.00 & 6212.83 & 3.88 & -26.41 & 10,183 & 0.70 & -26.40 \\
\hline $\begin{array}{c}\text { Central } \\
\text { Mac- } \\
\text { edonia }\end{array}$ & $19,12,624$ & 17.38 & -0.48 & $21,440.33$ & 13.38 & -23.03 & 11,210 & 0.77 & -22.65 \\
\hline $\begin{array}{c}\text { Western } \\
\text { Mac- } \\
\text { edonia }\end{array}$ & $2,81,324$ & 2.56 & -1.79 & 3901.29 & 2.43 & -14.66 & 13,868 & 0.95 & -13.11 \\
\hline Epirus & $3,43,128$ & 3.12 & -0.82 & 3538.35 & 2.21 & -21.81 & 10,312 & 0.71 & -21.16 \\
\hline Thessaly & $7,41,593$ & 6.74 & -0.72 & 8040.21 & 5.02 & -19.15 & 10,842 & 0.74 & -18.57 \\
\hline $\begin{array}{l}\text { Ionian } \\
\text { Islands }\end{array}$ & $2,08,241$ & 1.89 & -0.21 & 2719.88 & 1.70 & -25.77 & 13,061 & 0.90 & -25.62 \\
\hline $\begin{array}{l}\text { Western } \\
\text { Greece }\end{array}$ & $6,82,583$ & 6.20 & -1.40 & 7339.46 & 4.58 & -25.07 & 10,752 & 0.74 & -24.00 \\
\hline $\begin{array}{l}\text { Central } \\
\text { Greece }\end{array}$ & $5,60,093$ & 5.09 & 0.08 & 7162.06 & 4.47 & -21.21 & 12,787 & 0.88 & -21.27 \\
\hline $\begin{array}{l}\text { Pelopon- } \\
\text { nese }\end{array}$ & $5,86,863$ & 5.33 & -0.27 & 6959.91 & 4.34 & -19.59 & 11,860 & 0.81 & -19.37 \\
\hline Greece & $1,10,03,615$ & 100.00 & -1.04 & $1,60,236.70$ & 100.00 & -22.76 & 14,562 & 1.00 & -21.95 \\
\hline
\end{tabular}

tourism seems to have emerged in Greece where the clear losers are those regions that had specialized predominantly in domestic tourism.

\section{Empirical strategy and data treatment}

We use structural decomposition analysis (SDA) to identify the drivers of Greece's recession at the regional level between 2010 and 2013, from both the production side and the final demand side. From the production side, we analyse the impacts of changes in value-added generation and the production structure, taking into full consideration the systemic role of imported inputs, and inter-regional trade of intermediate goods. In the final demand side, we analyse the impacts of changes not only on the level, but also in the composition of final demand, especially capital investment, government expenditures and export demand of each region. We make use of a set of interregional inputoutput tables for Greece in the empirical analysis. ${ }^{5}$

\footnotetext{
${ }^{5}$ The database is available as a additional file.
} 


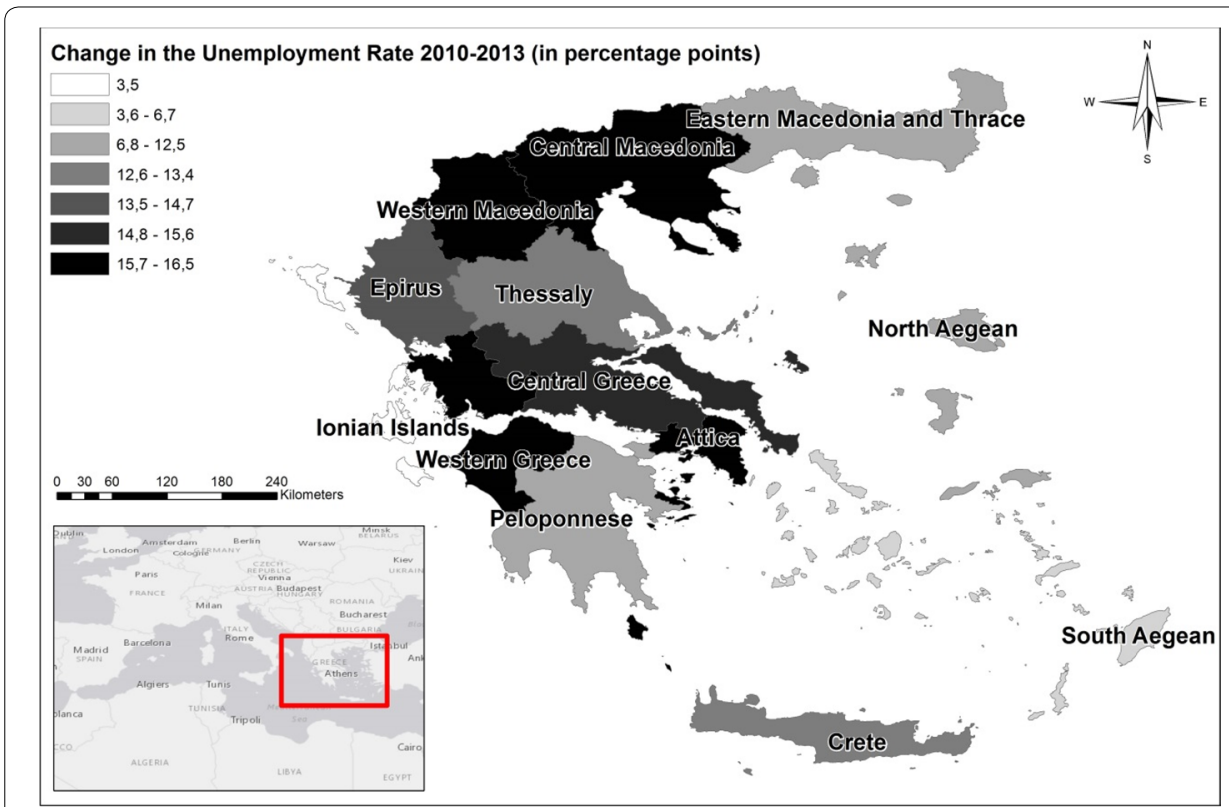

Source: EUROSTAT

Fig. 1 Change in regional unemployment rate: Greece, 2010-2013

\subsection{Structural decomposition analysis}

SDA aims at decomposing the total amount of change in some aspects of an economy. In an input-output framework, the total change in gross output-or in any economic variable that is function of it-can be broken into technical changes, final-demand changes, and other elements of the system. In the case of multi-regional systems, the Leontief-like multiplier matrix contains information on both technical coefficients and trade proportions (Miller and Blair 2009).

Considering that we have the input-output tables for 2 years, 2010 and 2013, we endogeneize the household sector so that we are able to incorporate links between factor payments and household expenditures. ${ }^{6}$ Moreover, we transform the Leontief matrix to make adequate comparisons in terms of income (value-added) multipliers. The use of value-added instead of gross output, not only is more adequate to couple the discussion to the Keynesian multiplier literature, but also it helps to unravel more accurately the role played by the service sectors in the Greek economy, usually with higher contents of value added per unit of output, and with an important role in the economic structure of the country. ${ }^{7}$

The closed input-output model, with $r$ regions, $n$ sectors and households endogenous, can be represented by

\footnotetext{
${ }^{6}$ One can move the household sector from the final-demand column and labor-input row and place it inside the technically interrelated table, making it one of the endogenous sectors. This is known as closing the model with respect to households. (...) It requires a row and a column of transactions for the new household sector-the former showing the distribution of its output (labor services) among the various sectors and the latter showing the structure of its purchases (consumption) distributed among the sectors (Miller and Blair 2009, pp 35).

7 The share of the tertiary sector in Greek GDP was 85.5\% in 2010, and 82.8\% in 2013.
} 


$$
\bar{x}^{t}=\bar{A}^{t} \bar{x}^{t}+\bar{f}^{t}
$$

and

$$
\bar{x}^{t}=\left(I-\bar{A}^{t}\right)^{-1} \bar{f}^{t}=\bar{L}^{t} \bar{f}^{t}
$$

where $\bar{x}^{t}$ denotes the $[r(n+1)]$-element column vector of gross outputs in year $t$; $\bar{f}^{t}$ the $[r(n+1)]$-element vector of final demands in year $t$; $\bar{A}^{t}$ the $[r(n+1)] \times[r(n+1)]$ inputoutput (or technical, or direct input) coefficients matrix with households included in year $t$; $I$ is the $[r(n+1)] \times[r(n+1)]$ identity matrix; and $\bar{L}^{t}$ is the $[r(n+1)] \times[r(n+1)]$ Leontief inverse or multipliers matrix in year $t$ for the closed model (household endogenous). ${ }^{8}$ The structures of the vectors and matrices relate to the dimensions $r$ (number of regions in the model) and $n$ (number of production sectors); $(n+1)$ refers to the number of production sectors and the household sector in each regional economy.

We can represent Eq. (2) in terms of value-added (rather than gross output) by using a set of value-added input coefficients-calculated as value-added (income) per euro of output in sector $n$ in region $r$ at time $t\left(v_{r n}^{t}\right)$. We can thus transform gross output in year $t$ $\left(x^{t}\right)$ into value added $\left(v^{t}\right)$, as shown in Eq. (3):

$$
v^{t}=\hat{v}^{t} \bar{x}^{t}=\hat{v}^{t} \bar{L}^{t} \bar{f}^{t}
$$

where $\hat{v}^{t}$ is a diagonal matrix with ratios of value added to gross output (value-added input coefficients) on the diagonal and zeros elsewhere (off-diagonal).

Then the observed change in value added over the period $(t=2010,2013)$ is

$$
\Delta v=v^{2013}-v^{2010}=\hat{v}^{2013} \bar{L}^{2013} \bar{f}^{2013}-\hat{v}^{2010} \bar{L}^{2010} \bar{f}^{2010} .
$$

In order to decompose the total change in value added using SDA and remove the influence of price changes, all data are expressed in prices of 2013. SDA can be defined as a way of distinguishing major sources of change in an economy. It involves a set of comparative static exercises in which sets of coefficients are changed, in turn, and activity levels compared to a reference point (Rose and Casler 1996, pp 34). In tandem with our interest in assessing structural changes in the context of the Greek crisis, it is important to focus on key parameters in the input-output system associated with the sources of changes one wants to analyse. Given the nature of our problem, whose focus lies on the role of the structural components that affect the size of the multipliers, one logical decomposition of changes in value added (3) can be represented as ${ }^{9}$ :

\footnotetext{
${ }^{8}$ See Miller and Blair (2009) for more details.

9 This is not the only decomposition possible. See Dietzenbacher and Los (1998) and Miller and Blair (2009) for a discussion of a wide variety of possible alternatives. We also refer to these authors for mathematical details, including additive decompositions with products of more than two terms. Given our choice for splitting the identity into the three components, the desirable property of Eq. (5) being completely exhaustive holds.
} 


$$
\begin{aligned}
\Delta v & =(1 / 2) \Delta \hat{v}\left(\bar{L}^{2010} \bar{f}^{2010}+\bar{L}^{2013} \bar{f}^{2013}\right) \\
& +(1 / 2)\left[\hat{v}^{2010}(\Delta \bar{L}) \bar{f}^{2013}+\hat{v}^{2013}(\Delta \bar{L}) \bar{f}^{2010}\right], \\
& +(1 / 2)\left(\hat{v}^{2010} \bar{L}^{2010}+\hat{v}^{2013} \bar{L}^{2013}\right)(\Delta \bar{f})
\end{aligned}
$$

where the first term on the right-hand side, $\Delta \hat{v}\left(\bar{L}^{2010} \bar{f}^{2010}+\bar{L}^{2013} \bar{f}^{2013}\right)$, is the valueadded input-coefficient change; the second term, $\left[\hat{v}^{2010}(\Delta \bar{L}) \bar{f}^{2013}+\hat{v}^{2013}(\Delta \bar{L}) \bar{f}^{2010}\right]$, is the direct-coefficient change; and the third term, $\left(\hat{v}^{2010} \bar{L}^{2010}+\hat{v}^{2013} \bar{L}^{2013}\right)(\Delta \bar{f})$, the final-demand change.

\subsection{Interregional input-output systems for Greece, 2010 and 2013}

The input-output tables used in our calculations reflect the economic structure of the Greek economy in two points in time (2010 and 2013). They consider the 13 NUTS 2 regions in Greece whose economies are disaggregated in 44 sectors. The tables are in constant 2013 prices. We have generated the database using the IIOAS (Interregional Input-Output Adjustment System) method. The IIOAS is a hybrid method that combines data made available by official agencies, such as the Hellenic Statistical Authority and EUROSTAT, with non-census techniques for the estimation of unavailable information. The main advantages of the IIOAS are its consistency with information from the National Accounts Statistics and the flexibility of its regionalization process, which can be applied to any country that: (i) publishes standard make and use tables; and (ii) provides a regional information system at the sectorial level. Such flexibility can be attested by recent applications for distinct interregional systems: interisland model for the Azores (Haddad et al. 2015), interregional models for Colombia (Haddad et al. 2016a), Egypt (Haddad et al. 2016b), Lebanon (Haddad 2014), Morocco (Haddad et al. 2017a), and Brazil (Haddad et al. 2017b). ${ }^{10}$

\subsubsection{Interregional linkages}

We can compute the contribution to regional income of final demand from different origins. In an integrated interregional system, regional income depends, among others, on demand originating in the region and, depending on the degree of interregional integration, on demand from outside the region.

Using basic input-output techniques, we consider the interdependence among sectors in different regions through the analysis of the complete direct coefficients portion of the interregional input-output table. To illustrate the nature of interregional linkages in Greece, we provide, in Tables 2 and 3, some summary indicators of the structure of the Greek economy derived from the Leontief inverse (multipliers) matrix for 2013.

The column multipliers derived from $\hat{v}^{2013} \bar{L}^{2013}$ were computed (see Miller and Blair 2009). An income or value-added multiplier is defined for each sector $j$, in each region $r$, as the total value added in across all sectors and regions of the economy that is necessary

\footnotetext{
${ }^{10}$ Detailed information on the estimation process of the 13 NUTS 2 regions input-output systems for Greece is documented in Haddad et al. (2018), available online at http://www.usp.br/nereus/wp-content/uploads/TD_Nereus_03_2018 pdf. Moreover, the database used in this paper can be downloaded assessing https://doi.org/10.13140/rg.2.2.25151.41124
} 
Table 2 Regional distribution of the average total value-added multipliers: Greece, 2013 (in \%). Source: Calculations by the authors

\begin{tabular}{|c|c|c|c|c|c|c|}
\hline \multirow[t]{2}{*}{ Regions } & \multicolumn{3}{|c|}{ Value added multiplier } & \multicolumn{3}{|c|}{ Net value added multiplier } \\
\hline & Total & $\begin{array}{l}\text { Intra- } \\
\text { regional } \\
\text { share }\end{array}$ & $\begin{array}{l}\text { Interregional } \\
\text { share }\end{array}$ & Net & $\begin{array}{l}\text { Intra- } \\
\text { regional } \\
\text { share }\end{array}$ & $\begin{array}{l}\text { Interregional } \\
\text { share }\end{array}$ \\
\hline Attica & 0.772 & 95.2 & 4.8 & 0.297 & 80.1 & 19.9 \\
\hline North Aegean & 0.710 & 87.2 & 12.8 & 0.284 & 47.6 & 52.4 \\
\hline South Aegean & 0.711 & 90.6 & 9.4 & 0.261 & 59.7 & 40.3 \\
\hline Crete & 0.740 & 91.6 & 8.4 & 0.280 & 66.6 & 33.4 \\
\hline Eastern Macedonia and Thrace & 0.729 & 83.6 & 16.4 & 0.286 & 38.4 & 61.6 \\
\hline Central Macedonia & 0.769 & 86.4 & 13.6 & 0.310 & 48.5 & 51.5 \\
\hline Western Macedonia & 0.708 & 81.1 & 18.9 & 0.287 & 28.0 & 72.0 \\
\hline Epirus & 0.742 & 81.9 & 18.1 & 0.312 & 35.3 & 64.7 \\
\hline Thessaly & 0.749 & 82.7 & 17.3 & 0.296 & 33.6 & 66.4 \\
\hline Ionian Islands & 0.681 & 86.8 & 13.2 & 0.258 & 50.1 & 49.9 \\
\hline Western Greece & 0.730 & 85.6 & 14.4 & 0.286 & 43.6 & 56.4 \\
\hline Central Greece & 0.751 & 78.8 & 21.2 & 0.286 & 30.9 & 69.1 \\
\hline Peloponnese & 0.753 & 82.7 & 17.3 & 0.302 & 36.4 & 63.6 \\
\hline
\end{tabular}

in order to satisfy a dollar's worth of final demand for sector $j$ 's output in r. The multiplier effect can be decomposed into intraregional (internal multiplier) and interregional (external multiplier) effects, the former representing the impacts on the value added across all sectors within the region where the final-demand change was generated, and the latter showing the impacts on the other regions of the system (interregional spillover effects). Formally, the column value-added multipliers are calculated as the column sums of $\hat{v}^{t} \bar{L}^{t}$, defined in Eq. (3). Let us write $\hat{v}^{t} \bar{L}^{t}$ as:

$$
\hat{v}^{t} \bar{L}^{t}=\left[\begin{array}{ccc}
\hat{v}_{1}^{t} & \cdots & 0 \\
\vdots & \ddots & \vdots \\
0 & \cdots & \hat{v}_{13}^{t}
\end{array}\right]\left[\begin{array}{ccc}
\bar{L}_{1,1}^{t} & \cdots & \bar{L}_{1,13}^{t} \\
\vdots & \ddots & \vdots \\
\bar{L}_{13,1}^{t} & \cdots & \bar{L}_{13,13}^{t}
\end{array}\right]=\left[\begin{array}{ccc}
\bar{L}_{1,1}^{t^{\prime}} & \cdots & \bar{L}_{1,13}^{t^{\prime}} \\
\vdots & \ddots & \vdots \\
\bar{L}_{13,1}^{t^{\prime}} & \cdots & \bar{L}_{13,13}^{t^{\prime}}
\end{array}\right],
$$

where again, $\hat{v}^{t}$ is a matrix with ratios of regional sectoral value added to gross output (value-added input coefficients) on the diagonal and zeros elsewhere (off-diagonal) and $\bar{L}^{t}$ is the Leontief inverse for the closed input-output model (household endogenous).

From Eq. (6), we can decompose each column value-added multiplier in its intraregional (internal multiplier) and interregional (external multiplier) effects. For region 1, for example, these multipliers are given, respectively, by

$$
\begin{aligned}
& m_{1 \text { (intra) }}^{t}=i\left[\hat{v}^{1} \bar{L}_{1,1}^{t}\right] \\
& m_{1 \text { (inter) }}^{t}=i\left[\hat{v}^{2} \bar{L}_{2,1}^{t}\right]+\cdots+i\left[\hat{v}^{13} \bar{L}_{13,1}^{t}\right],
\end{aligned}
$$

where $i$ is a row vector with all elements equal unity.

Analogously, we may have the column value-added multiplier and its decomposition to the other Greek regions. 


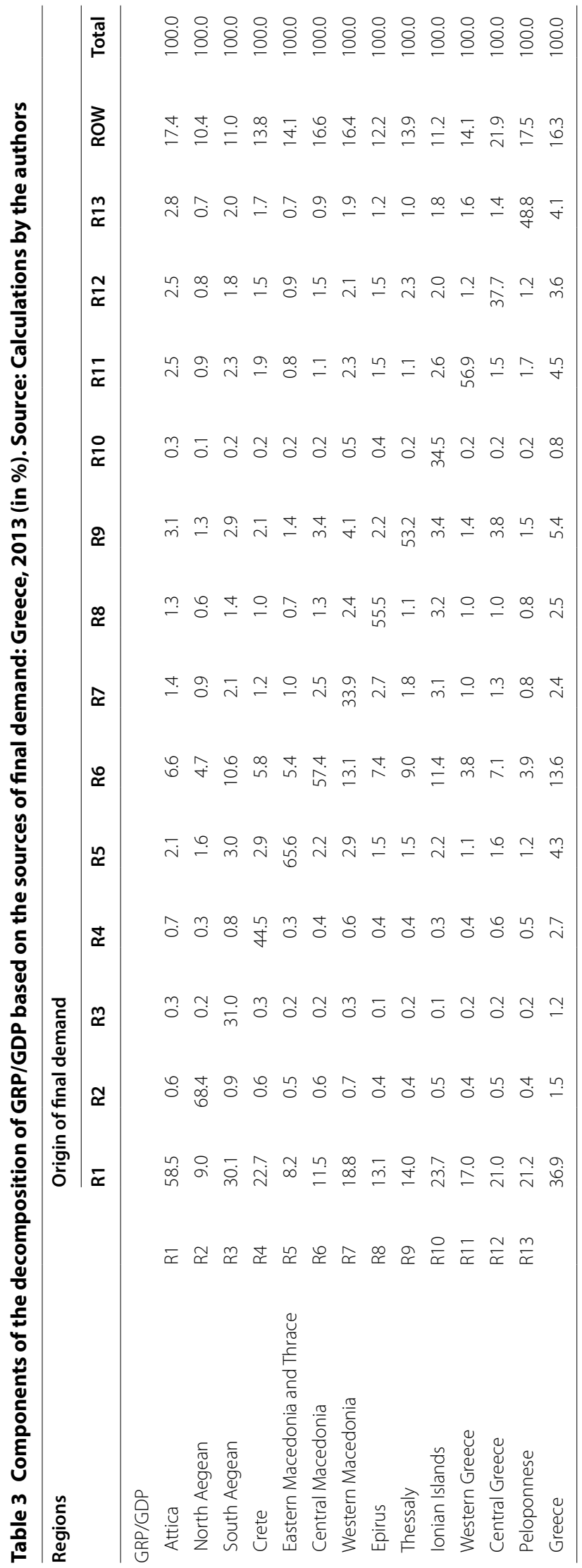


Table 2 shows the intraregional and interregional shares for the weighted average total value-added multipliers in the 13 NUTS 2 regions in Greece as well as the equivalent shares for the direct, indirect and induced effects of a unit change in final demand in each sector in each region net of the initial injection, i.e. the total income multiplier effect net of the initial change. The entries are shown in percentage terms, providing insights into the degree of dependence of each region on the other regions. Noteworthy are the results for Attica, the most self-sufficient region, where the average intraregional flow-on effects from a unit change in sectorial final demand are the highest: the average net effect exceeds $75 \%$. In other words, from the total value-added contents associated with a 1 Euro change in final demand in Attica, 90.5\% remain in the region; when we consider only the direct and indirect effects of such final-demand change, $75.2 \%$ of the value-added contents accrue to sectors in Attica. For some regions, located in Northern and Central Mainland Greece, the degree of regional self-sufficiency is much lower, and the intraregional flow-on effects, on average, are much lower than the total interregional effects.

A complementary analysis of the multiplier approach is presented in Table 3, in which we decompose regional income by taking into account not only the multiplier structure, but also the structure of final demand in the 13 domestic and the foreign regions (Sonis et al. 1996). We calculate the contributions of the components of final demand from different areas. The results reveal that, on average, the self-generated component of income in each region, i.e. the share of value added generated by demand within the region, is lower in those regions that present higher dependency upon the rest of the country and the rest of the world. The demand for foreign exports is very relevant for not only Attica, but also for other regions with bigger metropolitan areas such as Central Macedonia (Thessaloniki) and Central Greece (Patras). Its contribution can reach more than onefifth of the regional income ( $16.3 \%$ for the country as a whole), as is the case of Central Greece (21.9\%). There are also some cases of stronger dependency upon the rest of the country, as it is the case of the dependency of various regions on Attica's demand, and, to a lesser degree, the dependency of regions in the North of the country on Central Macedonia's demand.

A more systematic approach to visualize the influence of final demand from different regions is to map the column original estimates that generated Table 3 . The results, illustrated in Fig. 2, provide an attempt to reveal the spatial patterns of income dependence upon specific sources of final demand. The 13 regions are grouped in seven different categories in each map, so that darker colours represent higher values.

\section{Empirical results and main findings}

Table 4 presents the results of the SDA for total value added (see also Fig. 3). Greek GDP decreased $22.78 \%$ from 2010 to 2013. At the aggregate level, it reveals the qualitative results with GDP losses driven mainly by changes in final demand; a higher income multiplier associated with structural changes tends to increase national income, while the overall decrease in the value-added content in Greek gross output is relatively small.

Changes in final demand were the main factor during the period, reducing overall GDP in Greece by 57.4 billion Euros. They reflect the policy choices that led to recession. Changes in sectorial value-added coefficients had also a negative effect on national 


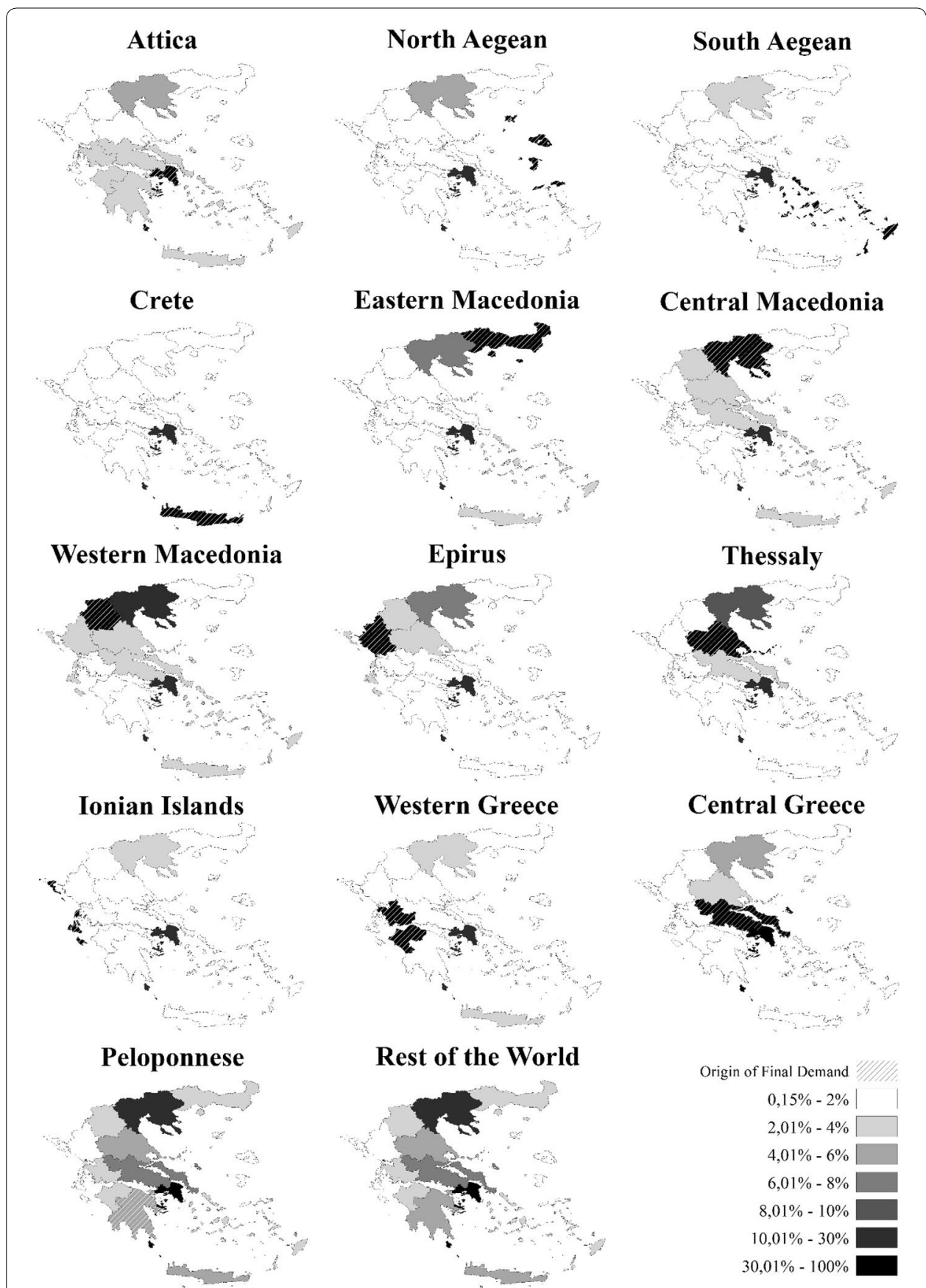

Fig. 2 Identification of regions relatively more affected by a specific regional demand, by origin of final demand

income. However, they are small (2.1 billion Euros) compared to the effects of changes in the final demand. In this case, the rapid deterioration of wages and profit rates in the first years of the Greek crisis led to a lower intensity in value added generation in the economy.

Changes in the direct input requirements between 2010 and 2013 would have helped GDP growth. Ceteris paribus, GDP in Greece would have grown 12.3 billion Euros (5.9\% 
Table 4 Driving forces of regional income: Greece, 2010-2013. Source: Calculations by the authors

\begin{tabular}{|c|c|c|c|c|c|c|c|c|}
\hline \multirow[t]{2}{*}{ Regions } & \multicolumn{2}{|c|}{$\begin{array}{l}\text { VA-input-coefficient } \\
\text { change }\end{array}$} & \multicolumn{2}{|c|}{ Direct-input change } & \multicolumn{2}{|c|}{ Final-demand change } & \multicolumn{2}{|l|}{$\Delta \mathrm{VA}$} \\
\hline & $\begin{array}{l}€ \\
\text { millions }^{\mathrm{a}}\end{array}$ & $\begin{array}{l}\text { Share } \\
(\%)\end{array}$ & $\begin{array}{l}€ \\
\text { millions }\end{array}$ & $\begin{array}{l}\text { Share } \\
(\%)\end{array}$ & $€$ millions $^{a}$ & $\begin{array}{l}\text { Share } \\
(\%)\end{array}$ & $€$ millions $^{a}$ & Share (\%) \\
\hline Attica & 710.50 & -3.00 & 6347.27 & -26.84 & $-30,707.24$ & 129.84 & $-23,649.47$ & 100 \\
\hline $\begin{array}{l}\text { North } \\
\text { Aegean }\end{array}$ & -71.84 & 11.21 & 150.87 & -23.55 & -719.70 & 112.34 & -640.67 & 100 \\
\hline $\begin{array}{l}\text { South } \\
\text { Aegean }\end{array}$ & 1.10 & -0.08 & 227.65 & -17.06 & -1563.49 & 117.14 & -1334.73 & 100 \\
\hline Crete & 175.01 & -7.38 & 164.72 & -6.95 & -2710.81 & 114.33 & -2371.07 & 100 \\
\hline $\begin{array}{l}\text { Eastern } \\
\text { Mac- } \\
\text { edonia } \\
\text { and } \\
\text { Thrace }\end{array}$ & -504.11 & 22.62 & 520.53 & -23.35 & -2245.51 & 100.74 & -2229.08 & 100 \\
\hline $\begin{array}{l}\text { Central } \\
\text { Mac- } \\
\text { edonia }\end{array}$ & -621.69 & 9.69 & 1475.05 & -23.00 & -7267.41 & 113.30 & -6414.05 & 100 \\
\hline $\begin{array}{c}\text { Western } \\
\text { Mac- } \\
\text { edonia }\end{array}$ & -66.95 & 9.99 & 537.25 & -80.14 & -1140.68 & 170.15 & -670.39 & 100 \\
\hline Epirus & -199.50 & 20.22 & 413.52 & -41.91 & -1200.76 & 121.69 & -986.74 & 100 \\
\hline Thessaly & -308.90 & 16.22 & 603.94 & -31.70 & -2199.92 & 115.49 & -1904.87 & 100 \\
\hline $\begin{array}{l}\text { Ionian } \\
\text { Islands }\end{array}$ & -285.01 & 30.18 & 310.52 & -32.88 & -969.99 & 102.70 & -944.49 & 100 \\
\hline $\begin{array}{l}\text { Western } \\
\text { Greece }\end{array}$ & -248.94 & 10.14 & 470.62 & -19.17 & -2676.82 & 109.03 & -2455.13 & 100 \\
\hline $\begin{array}{l}\text { Central } \\
\text { Greece }\end{array}$ & -83.01 & 4.31 & 269.20 & -13.97 & -2113.64 & 109.66 & -1927.45 & 100 \\
\hline $\begin{array}{l}\text { Pelopon- } \\
\text { nese }\end{array}$ & -619.69 & 36.56 & 862.08 & -50.85 & -1937.59 & 114.30 & -1695.20 & 100 \\
\hline Greece & -2123.03 & 4.50 & $12,353.23$ & -26.16 & $-57,453.56$ & 121.66 & $-47,223.36$ & 100 \\
\hline
\end{tabular}

${ }^{a}$ Euros millions of 2013

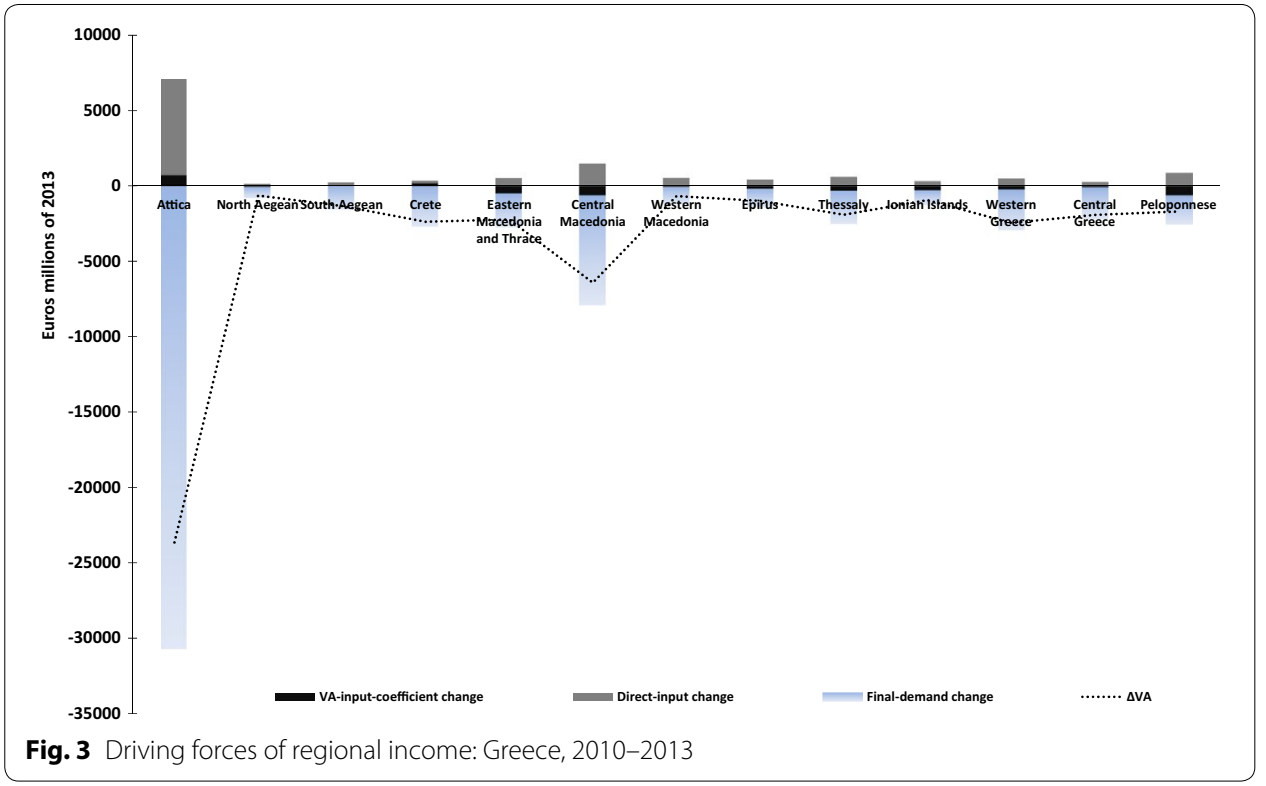




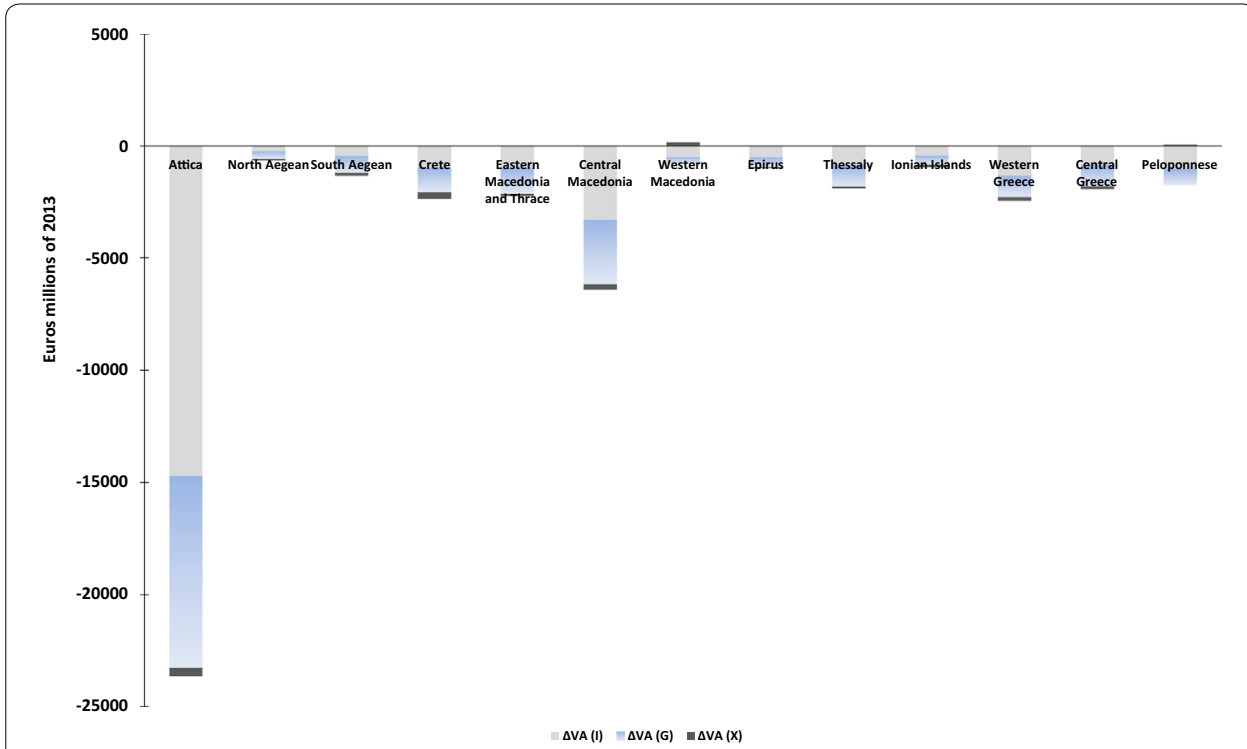

Fig. 4 GRP changes driven by final demand categories: Greece, 2010-2013. The figure represents the changes associated to each final demand component together with value-added input-coefficient change and direct-coefficient change. To have the contribution of each final demand component, we have considered each of them separately in the decomposition of changes in value-added, according to Eq. (5)

of 2010 GDP), reflecting, among others, a lower share of imported inputs. ${ }^{11}$ This result is particularly important for our discussion since it is associated with a higher level of the aggregate income multiplier in the structural setting of 2013 compared to 2010. As such, austerity policies adopted in Greece may have extended the negative impact of the 2008 financial crisis by slowing down the economic recovery and further deteriorating public finances.

Greek regions tend to differ in intensity, but not in the sign of the various components. An exception is changes in value-added coefficient. For instance, the share of labour and capital income in gross output for Attica and the islands in the southern Aegean (including Crete) tended to take positive effects, contrary to what we verified in the other regions of the country.

Final demand is collected and presented in several vectors, one for each final demand category, such as investments, government spending, and exports. We can dig deeper into the final demand vector and further decompose it into its main components. Considering each final demand component separately in Eq. (5), investment is the largest driver for GDP decrease. Investments together with value-added input-coefficient and direct-coefficient changes account for $55.6 \%$ of the total change in GDP. After investments, the effect associated with government spending causes the second largest decrease in GDP, of around 41.2\% between 2010 and 2013, while the remaining 3.2\% is associated with exports.

\footnotetext{
11 That is output growth due to changes in the intermediate demand per unit of output, or alternatively changes in the Leontief-inverse matrix of technical coefficients (holding constant total final demand). In this context, this component captures changes in the organization of production in the sectors, implying an increase in the intensity of demand for domestic intermediate inputs (Savona and Lorentz 2006).
} 
Table 5 Rate of change of the income multipliers: Greece, 2010-2013. Source: Calculations by the authors

\begin{tabular}{llrr}
\hline Regions & \multicolumn{2}{c}{$\Delta \%$} & \\
\cline { 2 - 4 } & Total & Intra & Inter \\
\hline Attica & 6.84 & 6.28 & 8.18 \\
North Aegean & 5.47 & -0.93 & 10.52 \\
South Aegean & 5.81 & 0.50 & 10.53 \\
Crete & 7.57 & 3.24 & 11.47 \\
Eastern Macedonia and Thrace & 3.69 & -4.74 & 10.36 \\
Central Macedonia & 5.52 & 0.38 & 10.58 \\
Western Macedonia & 1.31 & -2.93 & 4.35 \\
Epirus & 4.72 & -2.42 & 9.97 \\
Thessaly & 4.92 & -2.11 & 10.43 \\
lonian Islands & 3.32 & -4.18 & 9.54 \\
Western Greece & 6.37 & 0.36 & 11.26 \\
Central Greece & 4.51 & -2.52 & 9.62 \\
Peloponnese & 4.82 & -1.71 & 9.93 \\
Greece & 5.95 & - & - \\
\hline
\end{tabular}

Differences in the effects of final demand components and value-added input-coefficient and direct-coefficient changes were quite pronounced among regions. Figure 4 reveals more profound results on the contribution of components at the regional level. Ceteris paribus, changes in investments between 2010 and 2013 hampered GDP growth being responsible for a $-12.7 \%$ rate of the growth over the period. Changes in investment expenditures had substantial effects on GRP in Attica ( -14.7 billion Euros, equivalent to $14.5 \%$ of the region's 2010 GRP) and Ionian Islands ( -0.4 billion, $13.7 \%$ of GRP).

The effects associated with government demand changes represented $9.4 \%$ of Greece's 2010 GDP. They yielded above-average effects for Eastern Macedonia and Thrace (decreasing GRP by $-13.7 \%)$, North Aegean $(-11.7 \%)$, Ionian Islands $(-11.2 \%)$, South Aegean $(-11.1 \%)$, Crete $(-10.9 \%)$, Central Greece $(-10.5 \%)$ and Central Macedonia $(-10.3 \%)$.

Meanwhile, interactions of value-added input-coefficient and direct-coefficient changes with changes in exports decreased slightly GRP in Greece (1.5 billion Euros, $-0.7 \%$ of GDP). Nonetheless, the regional impacts were asymmetric. While some regions presented above-average relative losses in GRP (mainly the islands), two regions (Western Macedonia and Peloponnese) faced increases in their GRP associated with the performance of the export sector.

Information provided in Table 5 reinforces the case for qualified countercyclical regional policies in Greece (Psycharis et al. 2014; Artelaris 2017). It shows the percentage change in the size of the income multipliers for Greek regions, during 20102013. The multipliers were calculated as weighted averages of the regional sectorial value-added multipliers. Table 5 also shows the percentage changes in the average intra-regional and interregional multipliers, which allow us to understand better the region-specific potential for internalizing the impacts of expansionary fiscal regional policies within the territorial borders. 
This distinction is important to shed light on the efficacy of countercyclical regional policies. For a given region, a positive change in the intra-regional share of the income multiplier during the recession period suggests stronger responses to local fiscal stimulus. This is the case for Attica and Central Macedonia, regions that host the main metropolitan areas of the country, two of the most affected regions from 2010 to 2013. Three other regions (Crete, South Aegean, and Western Greece) also presented positive changes in the intra-regional component of their income multipliers. These areas, also, could potentially benefit more intensely from increasing government spending in their local economies.

In the case of the interregional parcel of the income multipliers, i.e. the part of the multiplier effect that leaks from the stimulated region, it seems to have increased in the period for all Greek regions. Such movement was due mainly to partial substitution away from international imports that presented, consistent with findings in other empirical studies (Palley 2009; Charles 2016), stronger reaction over the business cycle.

\section{Concluding remarks}

Throughout their lives, Keynes and Goodwin have shown genuine interest in the classical world. They both have spent time in Italy, where they have entertained themselves visiting different parts of the country (Davenport-Hines 2015; Di Matteo and Sordi 2015). This time we took them to a journey to Greece, in a virtual Grand Tour through the lenses of their intellectual legacy. We have explored the concept of the income multiplier in a multi-regional setting, in the context of the Greek crisis, showing empirical evidence for the increasing magnitude of the multiplier during the recession period.

The analysis in this paper found that from 2010 to 2013, around 55.6\% of the decline in Greece's GRP was due to the contraction in investments and $41.2 \%$ related to decreases in government spending. The dominance of these final demand components highlights the challenges strongly associated with the austerity policies undertaken to manage the crisis in Greece aiming to reduce the role of the public sector in the economy.

The analysis also showed that changes in inputs requirements (i.e. direct-input changes) between 2010 and 2013 aided GDP/GRP, reflecting positive changes in the income multipliers, although in different relative magnitudes in the regions. This set of results is consistent with earlier Keynesian policy prescriptions that recommended the expansion of government spending during recession periods. Putting this together with the SDA results for changes in final demand, it suggests that negative impacts on income in Greece were magnified by the increasing magnitude of the multipliers, not only in the country as a whole, but also in the regions.

These results reveal a complex system of interregional relations on some of its structural characteristics depend on the cyclical reaction paths of the regions (Isard 1960). In this case, the use of fiscal instruments to stimulate local activity in the regions may bring about important implications for regional inequality in Greece. As a further disaggregation of the interregional multiplier effects suggests (see Table 6 in Appendix), regions presenting consistently above-average increases in their share of the spillover effects 
from other regions could also indirectly benefit from government actions elsewhere in the country.

Finally, it is known that the decomposition in Eq. (5), which is based on mid-point weights for averaging the first and last years, is preferable to using either first-year weights or last-year weights alone. Nonetheless, the choice of reporting average effects also embeds some caveats, as the central problem with the application of decomposition techniques is to find appropriate weights (Dietzenbacher and Los, 1998). How sensitive the results from the exercise undertaken in this paper remain an empirical question.

Acknowledgements

Eduardo A. Haddad acknowledges financial support from CNPq and Fapesp. Vinicius A. Vale acknowledges financial support from Fipe.

Authors' contributions

EAH and VAV were responsible for the conception and design of the work; all authors contributed substantially to the analysis and interpretation of data, as well to drafting and revising the work. All authors read and approved the final manuscript.

\section{Funding}

CNPq (Grant 302861/2018-1); Brazilian Research Network on Global Climate Change FINEP/Rede CLIMA (Grant 01.13.0353-00); INCT-Climate Change Project Phase 2 (Grants FAPESP 2014/50848-9, CNPq 465501/2014-1, and CAPES/ FAPS No. 16/2014).

\section{Availability of data and materials}

The datasets (https://doi.org/10.13140/rg.2.2.25151.41124) generated and/or analysed during the current study are available in the ResearchGate repository, downloadable at: https://www.researchgate.net/publication/325049146_Interregio nal_Input-Output_Tables_for_Greece_2010_and_2013.

\section{Competing interests}

The authors declare that they have no competing interests.

\section{Author details}

${ }^{1}$ University of Sao Paulo, São Paulo, Brazil. ${ }^{2}$ Federal University of Minas Gerais, Belo Horizonte, Brazil. ${ }^{3}$ Department of Economics, FEAUSP, Av. Prof. Luciano Gualberto, 908, FEA I, Cidade Universitária, São Paulo, SP 05508-900, Brazil. ${ }^{4}$ Federal University of Parana, Curitiba, Brazil.

\section{Appendix}

See Table 6. 


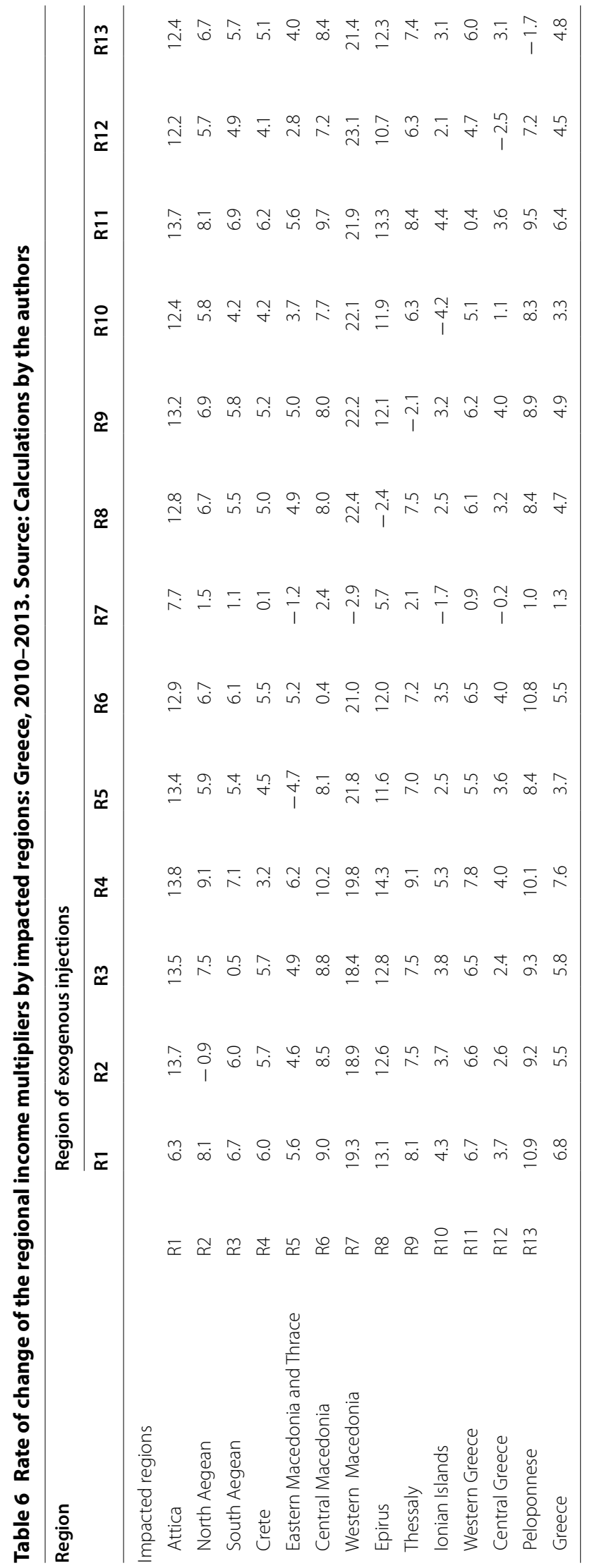


Received: 17 January 2019 Revised: 19 February 2020 Accepted: 9 April 2020 Published online: 18 April 2020

\section{References}

Artelaris P (2017) Geographies of crisis in Greece: a social well-being approach. Geoforum 84:59-69 Attaran M (1986) Industrial diversity and economic performance in U.S areas. Ann Reg Sci 20(2):44-54 Auerbach AJ, Gorodnichenko Y (2012) Measuring the output responses to fiscal policy. Am Econ J 4(2):1-27 Berry BJ (1988) Migration reversals in perspective: the long-wave evidence. Int Reg Sci Rev 11(3):245-251

Betz F, Carayannis E (2015) Why "Austerity" failed in Greece: testing the validity of macro-economic models. Mod Econ 6(6):672-686

Boyer R (2012) The four fallacies of contemporary austerity policies: the lost Keynesian legacy. Camb J Econ 36(1):283-312

Charles S (2016) An additional explanation for the variable Keynesian multiplier: the role of the propensity to import. J Post Keynesian Econ 39(2):187-205

Chipman JS (1950) The multi-sector multiplier. Econometrica 18(4):355-374

Davenport-Hines R (2015) Universal Man: The Lives of John Maynard Keynes. Hachette

Dewhurst JHL (1993) Decomposition of changes in input-output tables. Econ Syst Res 5(1):41-54

Di Matteo M, Sordi S (2015) Goodwin in Siena: economist, social philosopher and artist. Camb J Econ 39(6):1507-1527

Dietzenbacher E, Los B (1998) Structural decomposition techniques: sense and sensitivity. Econ Syst Res 10(4):307-324

Dietzenbacher E, Los B (2000) Structural decomposition analyses with dependent determinants. Econ Syst Res 12(4):497-514

Eraydin A (2016) Attributes and characteristics of regional resilience: defining and measuring the resilience of Turkish Regions. Reg Stud 50(4):600-614

Feldman SJ, McClain D, Palmer K (1987) Sources of structural change in the United States, 1963-78: an input-output perspective. Rev Econ Stat 69(3):503-510

Goodwin RM (1949) The multiplier as matrix. Econ J 59(236):537-555

Goodwin RM (1980) World Trade Multipliers. J Post Keynesian Econ 2(3):319-344

Haddad EA (2014) Trade and interdependence in lebanon: an interregional input-output perspective. J Dev Econ Policies 16(1):5-45

Haddad EA, Silva V, Porsse AA, Dentinho TP (2015) Multipliers in an island economy: the case of the Azores. In: Batabyal AA, Nijkamp P (eds) The region and trade: new analytical directions. World Scientific, Singapore, pp 205-226

Haddad EA, Faria WR, Galvis-Aponte LA, Hahn-De-Castro LW (2016a) Interregional Input-Output Matrix for Colombia, 2012, Borradores de Economia, no. 923, Banco de La Republica, Bogotá

Haddad EA, Lahr M, Elshahawany D, Vassallo M (2016b) Regional analysis of domestic integration in Egypt: an interregional CGE approach. J Econ Struct 5(1):1-33

Haddad EA, Ait-Ali A, El-Hattab F (2017a) A Practitioner's Guide for Building the Interregional Input-Output System for Morocco, 2013, OCP Policy Center Research Paper

Haddad EA, Gonçalves CA, Nascimento TO (2017b) Interstate Input-Output Matrix for Brazil: An Application of the IIOAS Method, Department of Economics, FEA-USP, Working Paper no. 2017-09

Haddad EA, Cotarelli N, Simonato T, Vale VA, Visentin J (2018) Estimation of NUTS2 interregional input-output systems for Greece, 2010 and 2013, TD NEREUS 03-2018. The University of São Paulo Regional and Urban Economics Lab (NEREUS)

Hewings GJD, Sonis M, Madden M, Kimura Y (eds) (1999) Understanding and interpreting economic structure. Springer, Berlin

Hitomi K, Okuyama Y, Hewings GJD, Sonis M (2000) The role of interregional trade in generatin change in regional economies of Japan, 1980-1990. Econ Syst Res 12(4):515-537

Isard W (1960) Methods of regional analysis: an introduction to regional science. The M.I.T Press, Cambridge

Kahn RF (1931) The relation of home investment to unemployment. Econ J 41(162):173-198

Karafolas S, Alexandrakis A (2015) Unemployment effects of the Greek crisis: a regional examination. Proc Econ Finan 19:82-90

Keynes JM (1936) The general theory of unemployment, interest and money. Macmillan, London

Krugman P (2013) How the Case for Austerity Has Crumbled, The New York Review of Books. http://www.nybooks.com/ articles/archives/2013/jun/06/how-case-austerity-has-crumbled/

Machlup F (1943) International trade and national income multiplier. AMK Reprints of Economic Clasics, New York

Martin R (2012) Regional economic resilience, hysteresis and recessionary shocks. J Econ Geogr 12(1):1-32

Martin R, Sunley P, Gardiner B, Tyler P (2016) How regions react to recessions: resilience and the role of economic structure. Reg Stud 50(4):561-585

Matsaganis M, Leventi C (2013) The distributional impact of the Greek crisis in 2010. Fiscal Stud 34(1):83-108

Metzler LA (1950) A multiple-region theory of income and trade. Econometrica 18(4):329-354

Miller RE, Blair PD (2009) Input-output analysis: foundations and extensions. Cambridge University Press, Cambridge

Miyazawa K (1976) Input-output analysis and the structure of income distribution. Springer, Heidelberg

Palley TI (2009) Imports and the income-expenditure model: implications for fiscal policy and recession fighting. J PostKeynesian Econ 32(2):311-322

Papadimitriou DB, Nikiforos M, Zezza G (2013a) The Greek economic crisis and the experience of austerity: a strategic analysis. The Levy Economics Institute of Bard College, Strategic Analysis, 1-25

Papadimitriou DB, Nikiforos M, Zezza G (2013b) A Levy Institute Model for Greece. Technical Paper, The Levy Economics Institute of Bard College

Papatheodorou A, Arvanitis P (2014) Tourism and the economic crisis in Greece - regional perspectives, Région et développement no. 39-2014 
Polak JJ (1957) Monetary analysis of income formation and payments problems. Int Monet Fund Staff Papers 6(1):1-50 Psycharis Y, Kallioras D, Pantazis P (2014) Economic crisis and regional resilience: detecting the 'geographical footprint' of economic crisis in Greece. Reg Sci Pol Pract 6(2):121-141

Reinhart CM, Rogoff KS (2010) Growth in a time of Debt. Am Econ Rev 100(2):573-578

Richardson HW (1969) Regional economics. Praeger, New York

Romero I, Dietzenbacher E, Hewings GJD (2009) Fragmentation and complexity: analyzing structural change in the Chicago regional economy. Revista de Economia Mundial 23:263-282

Rose A, Casler S (1996) Input-output structural decomposition analysis: a critical appraisal. Econ Syst Res 8(1):33-62 Savona M, Lorentz A (2006) Demand and technology contribution to structural change and tertiarisation: an inputoutput structural decomposition analysis, LEM Working Paper Series 2005/25

Solow R (2015) A couple of thoughts about the matrix multiplier: Richard Goodwin at $10 \times 10$. Camb J Econ 39(6):1529-1532

Sonis M, Hewings GJD, Lee JK (1993) Hierarquies of regional sub-structures and their multipliers within input-output systems: miyazawa revisited. Hitotsubashi J Econ 36(1):61-70

Sonis M, Hewings GJD, Gazel R (1995) The structure of multi-regional trade flows: hierarchy, feedbacks and spatial linkages. Ann Reg Sci 29(4):409-430

Sonis M, Hewings GJD, Guo J (1996) Sources of structural change in input-output systems: a field of influence approach. Econ Syst Res 8(1):15-32

Sonis M, Hewings GJD, Okuyama Y (2001) Feedback loops analysis of Japanese interregional trade, 1980-85-90. J Econ Geogr 1(3):341-362

Zhang H, Lahr ML (2014) China's energy consumption change from 1987 to 2007: a multi-regional structural decomposition analysis. Energy Policy 67:682-693

\section{Publisher's Note}

Springer Nature remains neutral with regard to jurisdictional claims in published maps and institutional affiliations.

\section{Submit your manuscript to a SpringerOpen ${ }^{\odot}$ journal and benefit from:}

- Convenient online submission

Rigorous peer review

Open access: articles freely available online

- High visibility within the field

Retaining the copyright to your article

Submit your next manuscript at $\boldsymbol{s p r i n g e r o p e n . c o m ~}$ 